\title{
Development of nanoemulsions with tucumã (astrocaryum vulgare) fruits oil
}

\begin{abstract}
Astrocaryum aculeatum is a palm species which belongs to the family Arecaeae, being commonly known as tucumã and widely distributed through Amazon. Tucumã fruit is a typically Amazonian raw material, which can be used for extraction of oil with great economic importance. However, to our knowledge, tucumã remain unexplored concerning development of a nanobiotechnology product. The aim of the present study was to develop nanoemulsions containing tucumã fruits oil. Formulations prepared with different blends of sorbitan monooleate and polysorbate 80 at HLB 11.0, 12.0, 12.25, 12.5, 12.75, 13.0, 13.25, $13.5,13.75$ and 14 were considered nanoemulsions. Smallest mean droplet $(156.6 \pm 0.6557$ $\mathrm{nm}$ ) was observed for nanoemulsion at HLB 13, which was considered required HLB value of this oil. On this context, this study provides valuable information concerning nanobiotechnology of Amazonian oils with great interest for pharmaceutical, cosmetics and food industries.
\end{abstract}

Keywords: HLB, Nanoemulsion, Tucumã
Volume 2 Issue 2 - 2015

\author{
Carla NS Silva,' Danilo C Hyacienth, ${ }^{2}$ \\ Adriana M Ferreira, ${ }^{3}$ Jessica CEVilhena, ${ }^{3}$ \\ Alexandro C Florentino, ${ }^{4}$ Rodrigo AS Cruz, ${ }^{2}$ \\ Didier Bereau,' Jean-charles Robinson,' Jose \\ CT Carvalho, ${ }^{3}$ Caio P Fernandes ${ }^{2}$ \\ 'UMR Qualitrop, Universite des Antilles et de la Guyane, France \\ 2Laboratorio de Nanobiotecnologia Fitofarmaceutica - \\ Colegiado de Farmacia, Universidade Federal do Amapa, Brazil \\ ${ }^{3}$ Laboratorio de Pesquisa em Farmacos, Universidade Federal do \\ Amapa, Brazil \\ ${ }^{4}$ Laboratorio de Absorcao At
}

\begin{abstract}
Correspondence: Caio Pinho Fernandes, Laboratorio de Nanobiotecnologia Fitofarmaceutica - Colegiado de Farmacia, Universidade Federal do Amapa, Macapa, AP, Brazil, Tel
\end{abstract} 055(96)4009-2927 Email caio_pfernandes@yahoo.com.br

Received: October 0I, 2015 | Published: April 0I, 2015

\section{Introduction}

Astrocaryum aculeatum is a palm species which belongs to the family Arecaeae, being commonly known as tucumã and distributed through North (Acre, Amazonas, Pará, Rondônia, Roraima) and Central-West (Mato-Grosso) regions of Brazil. ${ }^{1-3}$ It is also found through other countries, such as Bolivia, Colombia, French Guiana, Suriname, Venezuela and Trinidad and Tobago ${ }^{4}$ Several biological activities, including anti-inflammatory. ${ }^{5,6}$ antibacterial and antifungal. ${ }^{7}$ properties have been reported for this species. Its fruits are important sources of minerals, including potassium, calcium, selenium and present great amounts of fatty acids. ${ }^{8}$ being indicated for the treatment of skin and eye diseases. ${ }^{9}$ Tocopherols, phytosterols, quercetin, rutin, gallic and cafeic acids have also been previously described as chemical constituents of tucumã. ${ }^{5,710,11}$ Due to its high nutritional value and pleasant taste, tucumã fruits are widely consumed by local population as food, being used in natura andto produce ice cream, dessert, cakes and sandwiches. ${ }^{12,13}$ Tucumã fruit is a typically Amazonian raw material, which can be used for extraction of an oil with great economic importance. ${ }^{1,14}$ Oleic acid is a fatty acid constituent of this oil, however, carotenoids develop a main role as bioactive substances, being $b$ - carotene the major substance. This substance is a pro-vitamin A and found in tucumã in higher concentrations than in carrot. ${ }^{10,13}$

Nanotechnology involves manipulation of materials and structures in a nanometric scale, being considering a promising tool to develop innovative pharmaceutical, cosmetics and food products. ${ }^{15}$ Concerning food nanotechnology, studies have focused mainly to food packaging. ${ }^{16}$ or development of a wide range of nano formulations. ${ }^{17-19}$ On this context, nanoemulsions appear as promising food products..$^{20}$ They have small droplets ranging from $30-300 \mathrm{~nm} .{ }^{21}$ which are associated to kinetic stability of these systems, being also associated to increased absorption and potential bioavailability of substances. ${ }^{22}$ Despite great potential of tucumã, to our knowledge, its fruits remain unexplored concerning development of a nanobiotechnology product. The aim of the present study was to develop nanoemulsions containing tucumã fruits oil.

\section{Materials and methods}

\section{Chemicals}

Sorbitan oleate (HLB: 4.3) and Polysorbate 80 (HLB: 15) were purchased from Praid Produtos Quimicos Ltda (São Paulo, Brazil). Astrocaryum aculeatumripe fruits were harvested in Cayenne (French Guyane) and identified by Dr. Didier Bereau.

\section{Tucumã oil extraction}

$30 \mathrm{~g}$ of fresh pulp of tucumã were extracted with $300 \mathrm{~mL}$ of cyclohexane using a Soxhlet apparatus for 2 hours. Further removement of organic solvent was performed using a rotary evaporator under 35 ${ }^{\circ} \mathrm{C}$. Tucumã oil was stored in amber glass flask under $4^{\circ} \mathrm{C}$ until it was used for nano emulsion preparation.

\section{Emulsification method}

Emulsions were prepared by phase inversion technique with some modifications [24]. Required amounts of both emulsifiers were dissolved in tucumã oil and heated at $65 \pm 5^{\circ} \mathrm{C}$. Aqueous phase was separately heated at $65 \pm 5^{\circ} \mathrm{C}$. When both phases reached the same temperature, aqueous phase was continuously added through the oil phase. The mixture was submitted to magnetic agitation for 10 min, furnishing a primarily emulsion. Final homogenization was achieved using a T25 Ultra-Turrax homogenizer (Ika-Werke, Staufen, Germany) equipped with a $25 \mathrm{~N}-18 \mathrm{G}$ disperser for $5 \mathrm{~min}$ (8000 rpm).

\section{Required HLB determination of tucumã oil}

Each emulsion was prepared at a final mass of $25 \mathrm{~g}$, containing 90 $\%(\mathrm{w} / \mathrm{w})$ of distilled water, $5 \%(\mathrm{w} / \mathrm{w})$ of tucumã oil and $5 \%(\mathrm{w} / \mathrm{w})$ of a mixture of emulsifiers [23-24]. Series of emulsions were prepared using sorbitan monooleate as most hydrophobic emulsifier, and polysorbate 80 as most hydrophilic emulsifier. HLB values ranging from $4.3(5 \% \mathrm{w} / \mathrm{w}$ of sorbitan oleate) to $15(5 \% \mathrm{w} / \mathrm{w}$ of polysorbate 80 ) were prepared by blending together emulsifiers in different ratios. Required HLB value of tucumã fruits oil was determined as the HLB 
of surfactant or surfactants mixture which was able to achieve the most stable formulation.

\section{Characterization of emulsions}

Formulations were characterized after 1 and 7 days of manipulation. Macroscopical aspects (appearence, translucence, opacity, bluish reflect, phase separation, creaming and sedimentation) were examined. Polidispersity and mean droplet size were determined by photon correlation spectroscopy using a Zetasizer 5000 (Malvern Instruments, Malvern, UK). Each emulsion was diluted using ultrapure Milli-Q water (1:25). Measures were performed in triplicate and average droplet size was expressed as the mean diameter.

\section{Results and discussion}

Studies focusing on HLB determination of oils are very important if development of emulsions is desired and is considered a valuable tool during development stage..$^{25}$ including for nanoemulsions. This can be obtained by calculation the HLB value of a single surfactant or a blend of surfactants which induce formation of the most stable emulsion, among a set of formulations with different surfactant ratios in a wide range of HLB values..$^{26}$ On this context, several emulsions were prepared using tucumã fruits oil using a pair of lipophilic (sorbitan monooleate) and hydrophilic (polysorbate 80) surfactants. Set of formulations was prepared with HLB values ranging from 4.3 (HLB of sorbitan monooleate) to 15 (HLB of polysorbate 80). Emulsions prepared with HLB of 4.3,5,6,7,8 and 9 presented milky aspects, besides signals of instable behavior, including high levels of creaming and phase separation. Moreover, mean droplet size above $300 \mathrm{~nm}$ and high polidispersity (data not shown) suggested absence of kinetic stability, which is an intrinsic characteristic of nanoemulsions. ${ }^{27}$

Formulation prepared with HLB of 10 presented mean droplet size below $300 \mathrm{~nm}(282.9 \pm 8.266 \mathrm{~nm})$ after one day of preparation, however, this size increased to $312.6 \pm 5.609 \mathrm{~nm}$ after seven days of storage. Polidispersity also increased, revealing a polimodal distribution. Coalescence of the droplets may be attributed to these effects, being associated to the inability of surfactant to absorb to the interface. ${ }^{28}$ It was observed a decrease in the mean droplet size of formulations prepared with surfactants at HLB values of 11, 12 and 13 . They ranged from $305.6 \pm 5.782$ (HLB 11), $233.4 \pm 3.032 \mathrm{~nm}$ (HLB 12) and 198.9 \pm 1.601 (HLB 13) after 1 day of preparation to $211.5 \pm 6.825$ (HLB 11), 190.1 \pm 7.736 (HLB 12) and 156.6 \pm 0.6557 (HLB 13) after 7 days of preparation. Utilization of volatile organic solvent may be associated to this phenomenon, considering that evaporation of residual solvent during storage may decrease droplet diameter. ${ }^{20}$ Mean droplet size for formulation with HLB of 14 increased (219.8 111.20 $\mathrm{nm}$ after 1 day and $236.5 \pm 7.317 \mathrm{~nm}$ after 7 days). Considering that polidispersity did not present significant variation, this increase may be associated to destruction and regeneration of the micelles. ${ }^{29}$

Additional formulations were prepared with HLB values close to 13 , which presented the smallest droplet size $(156.6 \pm 0.6557 \mathrm{~nm})$ and polidispersity $(0,240 \pm 0,006)$ after seven days of storage. Mean droplet size analysis revealed that these formulations presented values between 300-200 nm after 7 days of preparation, being also characterized as nanoemulsions. Mean droplet size and polidispersity are presented in Table 1.

Formulation in which HLB value of surfactants coincide with required HLB of the oil can be determined, considering that it should present the smallest mean droplet among a set of emulsions prepared with different ratios of a pair of surfactants. ${ }^{23}$ On this context, it was possible to determine tucumã fruits oil at HLB 13. Mean droplet size distribution and polidispersity index is shown at Figure 1. Determination of required HLB value of oils has been successfully used to achieve small droplets in a nano size range. ${ }^{23,24,30}$

Table I Mean droplet size and polidispersity of emulsions prepared during required HLB determination of tucuma fruits oil

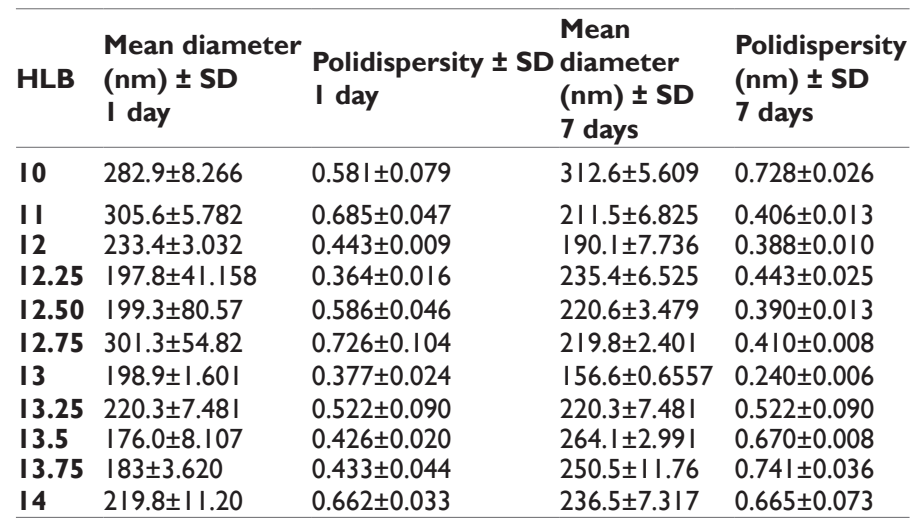

HLB Balance hydrophilic-lipophilic; nm: nanometer
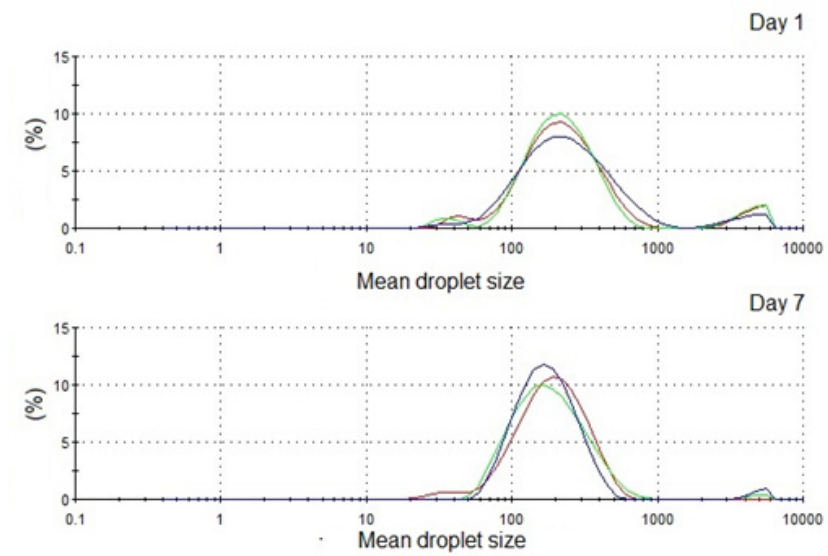

Figure I Mean droplet size and polidispersity of nanoemulsions prepared with $5 \%(w / w)$ of tucuma oil, $5 \%(w / w)$ of surfactants (HLB I3) and $90 \%(w / w)$

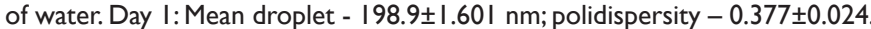

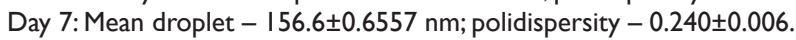

On the present study, formulations at HLB 11.0, 12.0, 12.25, 12.5, $12.75,13.25,13.5,13.75$ and 14 were considered nanoemulsions. These are a special type of nano formulation with mean droplet ranging from $30-300 \mathrm{~nm}$, being characterized by the dispersion of two immiscible liquids and presence of one or more surfactants. ${ }^{21}$ They are also called mini emulsions. ${ }^{31}$ and small droplets are associated to kinetic stability of these systems, being also associated to increased absorption and potential bioavailability of substances. ${ }^{22}$ Development of nanoemulsions as enhancers of chemical stability of natural products is considered promising, allowing, protection of substances from degradation, including oxidation..$^{32}$ Moreover, nanoemulsions prepared with carotenoids have been considered potential food products and are in the spotlight of nanobiotechnology research..$^{20}$

\section{Conclusion}

The present study allowed achievement of nanoemulsions using different blends of non-ionic surfactants. Moreover, considering the lowest mean droplet ( $156.6 \pm 0.6557 \mathrm{~nm}$ ) observed after seven days of storage, it was possible to determine required HLB value of this oil (HLB 13). On this context, this study provides valuable information 
concerning nanobiotechnology of Amazonian oils with great interest for pharmaceutical, cosmetics and food industries.

\section{Acknowledgements}

Authors would like to thank CNPQ and FAPEAP for their financial support.

\section{Conflicts of interest}

None.

\section{References}

1. Schroth G, Mota MSS, Lopes R et al. Extractive use, management and in situ domestication of a weedy palm, Astrocaryum tucuma, in the central Amazon. Forest Ecology and Management. 2004;202(1-3): $161-179$.

2. Filho OCS, Sagrillo MR, Garcia LFM et al. The In Vitro Genotoxic Effect of Tucuma (Astrocaryum aculeatum), an Amazonian Fruit Rich in Carotenoids. J Med Food. 2013;16(11):1013-1021.

3. Leitman P, Henderson A, Noblick L et al. Astrocaryum Aculeatum. Lista de Espécies da Flora do Brasil. Jardim Botânico do Rio de Janeiro. 2014

4. Meyer, Wilhelm GF Astrocaryum Aculeatum Tropicos ${ }^{\circledR}$ Missouri Botanical Garden. 2014

5. Bony E, Boudard F, Brat P et al. Awara (Astrocaryum vulgare M.) pulp oil: Chemical characterization, and anti-inflammatory properties in a mice model of endotoxic shock and a rat model of pulmonary inflammation. Fitoterapia. 2012;83(1):33-43.

6. Bony E, Boudard F, Brat P et al. Chemical Composition and Antiinflammatory Properties of the Unsaponifiable Fraction from Awara (Astrocaryum vulgare M.) Pulp Oil in Activated J774 Macrophages and in a Mice Model of Endotoxic Shock. Plant Foods Hum Nutr. 2012;67(4):384-392.

7. Jobim ML, Santos RCV, Alves CFS et al. Antimicrobial activity of Amazon Astrocaryum aculeatumextracts and its association to oxidative metabolism. Microbiol Res. 2014;169(4):314-323.

8. Yuyama LKO, Aguiar JPL, Teixeira AP et al. Polpa e casca de Tucumã (Astrocaryum aculeatum) quais os constituintes nutricionais? Nutr 332. 2005

9. Kahn F The genus Astrocaryum (Arecaceae). El género Astrocaryum (Arecaceae). Rev Peru Biol. 2008;15(1):31-48.

10. Rosso VV, Mercadante AZ Identification and Quantification of Carotenoids, By HPLC-PDA-MS/MS, from Amazonian Fruits. J Agric Food Chem. 2007;55(13):5062-5072.

11. Gonçalves AESS, Lajolo FM, Genovese MI Chemical composition and antioxidant/antidiabetic potential of Brazilian native fruits and commercial frozen pulps. J Agric Food Chem. 2010;58(8):666-4674.

12. Lira CS, Berruti FM, Palmisano P et al. Fast pyrolysis of Amazon tucumã (Astrocaryum aculeatum) seeds in a bubbling fluidized bed reactor. Journal of Analytical and Applied Pyrolysis. 2013;99:23-31.

13. Yuyama LKO, Maeda RN, Pantoja L et al. Processamento e avaliação da vida-de-prateleira do tucumã (Astrocaryum aculeatum Meyer) desidratado e pulverizado. Ciênc Tecnol Aliment. 2008;28(2): 408-412.

14. Barbosa BS, Koolen HHF, Barreto AC et al. Aproveitamento do Óleo das Amêndoas de Tucumã do Amazonas na Produção de Biodiesel. Acta Amazônica. 2009;39(2):371-376.
15. Brumfiel G Consumer products leap aboard the nano bandwagon. Nature. 2006;440(7082):262.

16. Duncan TD Applications of nanotechnology in food packaging and food safety: Barrier materials, antimicrobials and sensors. Journal of Colloid and Interface Science. 2011;363(1):1-24.

17. Gomes LMM, Petito N, Costa Vg et al. Inclusion complexes of red bell pepper pigments with b-cyclodextrin: Preparation, characterisation and application as natural colorant in yogurt. Food Chem. 2014;148:428-436.

18. Surassmo S, Min S, Bejrapha P, Choi M Effects of surfactants on the physical properties of capsicum oleoresin-loaded nanocapsules formulated through the emulsion-diffusion method. Food Research International. 2010;43(1):8-17.

19. Leong W, Lai O, Long K et al. Preparation and characterisation of water-soluble phytosterol nanodispersions. Food Chemistry. 2011;129(1):77-83.

20. Silva HD, Cerqueira MA, Souza BWS, Ribeiro C et al. Nanoemulsions of b-carotene using a high-energy emulsification-evaporation technique. Journal of Food Engineering. 2011;102(2):130-135.

21. Zhang Y, Gao J, Zheng $\mathrm{H}$ et al. The preparation of 3,5-dihydroxy-4isopropylstilbene nanoemulsion and in vitro release International. Int $J$ Nanomedicine. 2011;6:649-657.

22. Solans C, Izquierdo P, Nolla L et al. Nano-emulsions. Current Opinion in Colloid \& Interface Science. 2005;10(3-4):102-110.

23. Fernandes CP, Mascarenhas MP, Zibetti FM et al. HLB value, an important parameter for the development of essential oil phytopharmaceuticals. Revista Brasileira de Farmacognosia. 2013;23(1):108-114.

24. Costa IC, Rodrigues RF, Almeida FB et al. Development of Jojoba Oil (Simmondsia chinensis (Link) CK Schneid.) Based Nanoemulsions. Latin American Journal of Pharmacy. 2014;33(3):459-63.

25. Schmidts T, Dobler D, Gulda AC et al. Multiple W/O/W emulsionsUsing the required HLB for emulsifier evaluation. Colloids and Surfaces A: Physicochem Eng Aspects. 2010;372(1-3):48-54.

26. Rodríguez-Rojo S, Varona S, Núñez $\mathrm{M}$ et al. Characterization of rosemary essential oil for biodegradable emulsions. Industrial Crops and Products. 2012;37(1):137-140.

27. Tadros T, Izquierdo P, Esquena $\mathrm{J}$ et al. Formation and stability of nanoemulsions. Adv Colloid Interface Sci. 2004;108-109:303-318.

28. Kentish S, Wooster TJ, Ashokkumar M et al. The use of ultrasonics for nanoemulsion preparation. Innovative Food Science and Emerging Technologies. 2008;9(2):170-175.

29. Patist A, Kanicky JR, Shukla PK et al. Importance of Micellar Kinetics in Relation to Technological Processes. J Colloid Interface Sci. 2002;245(1):1-15.

30. Fernandes CP, Almeida FB, Silveira AN et al. Development of an insecticidal nano emulsion with Manilkara subsericea(Sapotaceae) extract. J Nanobiotechnology. 2014;12:22.

31. Forgiarini A, Esquena J, González C et al. Studies of the relation between phase behavior and emulsification methods with nanoemulsion formation. Progr Colloid Polym Sci. 2000;115:36-39.

32. Dias DO, Colombo M, Kelmann RG et al. Optimization of headspace solid phase microextraction for analysis of b-caryophyllene in a nanoemulsion dosage form prepared with copaiba (Copaifera multijuga Hayne) oil. Anal Chim Acta. 2012;721:79-84. 